\title{
DEGRADATION OF ICE-FORMED BEACH DEPOSITS
}

PETER S. ROSEN

Atlantic Geoscience Centre, Geological Survey of Canada, Bedford Institute of Oceanography, Dartmouth, Nova Scotia, CANADA

Ice-push ridges and kaimoos are depositional features formed by ice on Tabusintac Beach, New Brunswick. These features are transformed into ridge-and-runnel systems when subjected to wave processes. Kaimoo and ice-push ridges l) protect the beach from storms for a few-week period, 2) induce deposition of sand at the upper beachface and 3) leave a lag deposit of cobble which may be a significant source of cobble transported across the beachface during sumer storms.

\section{INTRODUCTION}

The form and processes of degradation of iceformed beach features were investigated on Tabusintac Beach, New Brunswick in 1977. The study area was located on a sandy barrier situated on the west coast of the southern Gulf of St. Lawrence (Fig. 1). This microtidal environment has mixed, semidiurnal tides with a mean range of $0.8 \mathrm{~m}$ and spring range of $1.2 \mathrm{~m}$. Ice is present as floes, or close pack for up to five months each year (Matheson 1967) and it plays an important role in limiting wave action during the winter.

The freeze-up and thaw sequence at Richibucto Head, $75 \mathrm{~km}$ south of Tabusintac was monitored by Owens (1976). Although the structure of the ice on the shore was described in that study, it did not indicate movement of sediment resulting from ice, which is considered in the present study.

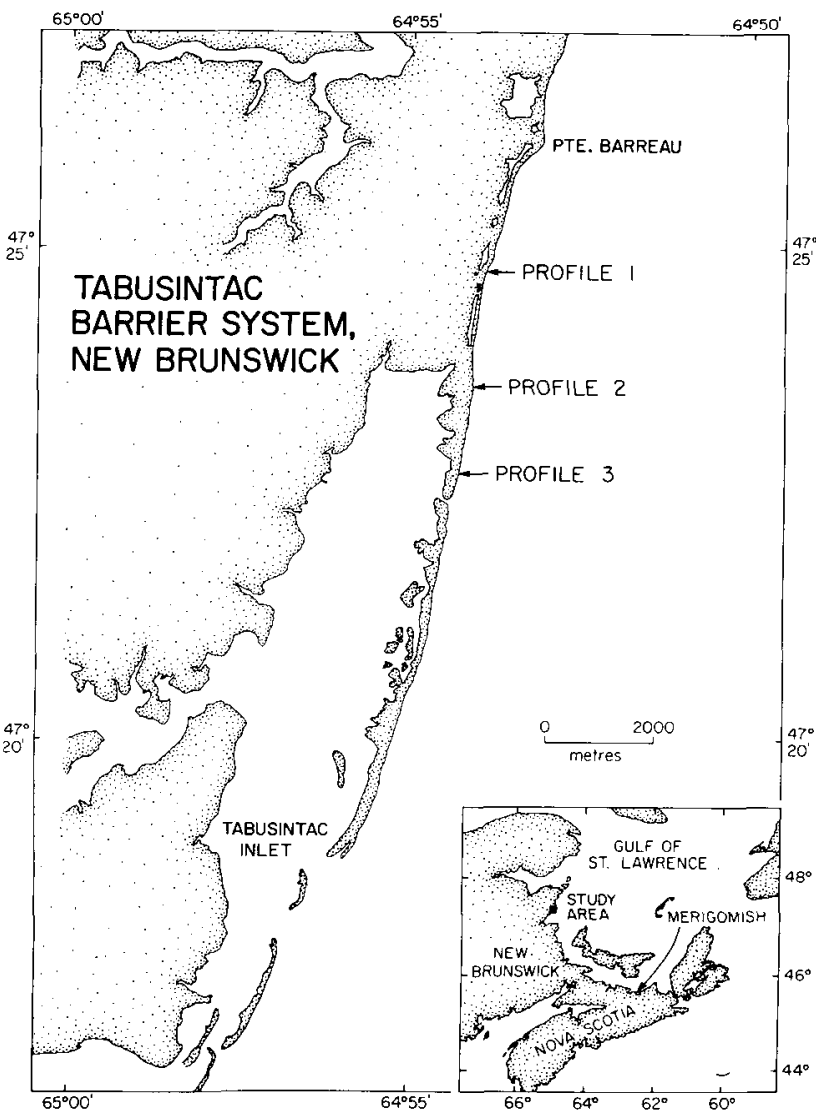

FIG. 1 Location of Tabusintac Beach and the profile network.
The winter of 1977 was particularly cold. Table 1 shows mean daily temperatures compared with 29-year averages for Chatham, New Brunswick, (Atmospheric Environment Service 1973). In December and January, the freeze-up period, mean temperatures and mean minimum temperatures were about $4 \mathrm{C}$ lower than the normals. February was also slightly coldex than the normals. This accounts for greater sediment movement by ice due to the formation of a thicker winter ice cover.

TABLE I

\begin{tabular}{|c|c|c|c|}
\hline \multicolumn{4}{|c|}{ Chatham Temperature Data $\left({ }^{\circ} \mathrm{C}\right)$} \\
\hline \multicolumn{4}{|c|}{1941 - 1970 Averages } \\
\hline & $\begin{array}{c}\text { Mean } \\
\text { Daily } \\
\text { Minimum }\end{array}$ & $\begin{array}{c}\text { Mean } \\
\text { Daily }\end{array}$ & $\begin{array}{c}\text { Mean } \\
\text { Daily } \\
\text { Maximum }\end{array}$ \\
\hline $\begin{array}{l}\text { December } \\
\text { January } \\
\text { February } \\
\text { March } \\
\text { April } \\
\text { May }\end{array}$ & $\begin{array}{l}-11.1 \\
-14.4 \\
-14.2 \\
-8.3 \\
-2.1 \\
+3.5\end{array}$ & $\begin{array}{l}-6.7 \\
-9.6 \\
-8.6 \\
-3.4 \\
+2.9 \\
+9.6\end{array}$ & $\begin{array}{r}-2.2 \\
-4.6 \\
-3.1 \\
+1.4 \\
+7.9 \\
+15.6\end{array}$ \\
\hline \multicolumn{4}{|c|}{$1977 / 78$ Averages } \\
\hline . & $\begin{array}{c}\text { Mean } \\
\text { Daily } \\
\text { Minimum }\end{array}$ & $\begin{array}{c}\text { Mean } \\
\text { Daily }\end{array}$ & $\begin{array}{c}\text { Mean } \\
\text { Daily } \\
\text { Maximum }\end{array}$ \\
\hline & $\begin{array}{l}-16.7 \\
-18.9 \\
-14.4 \\
-5.7 \\
-3.7 \\
+\quad 2.8\end{array}$ & $\begin{array}{l}-10.5 \\
-12.4 \\
-9.0 \\
-0.9 \\
+2.1 \\
+9.9\end{array}$ & $\begin{array}{r}-4.2 \\
-5.8 \\
-3.5 \\
+4.0 \\
+7.9 \\
+17.0\end{array}$ \\
\hline
\end{tabular}

\section{ICE FEATURES}

Two common ice features were observed at Tabusintac Beach: kaimoo and ice-push ridges. Kaimoo is a rampart of alternating layers of beach sediment and ice and is often convex upwards in profile (Rex 1964). Moore (1966) and MCCann and Carlisle (1972) ascribed the kaimoo to be "a result of swash action in a non-tidal or microtidal environment: it is build up above still water level, and usually contains interbedded sediment washed up from the water-covered beach below." 


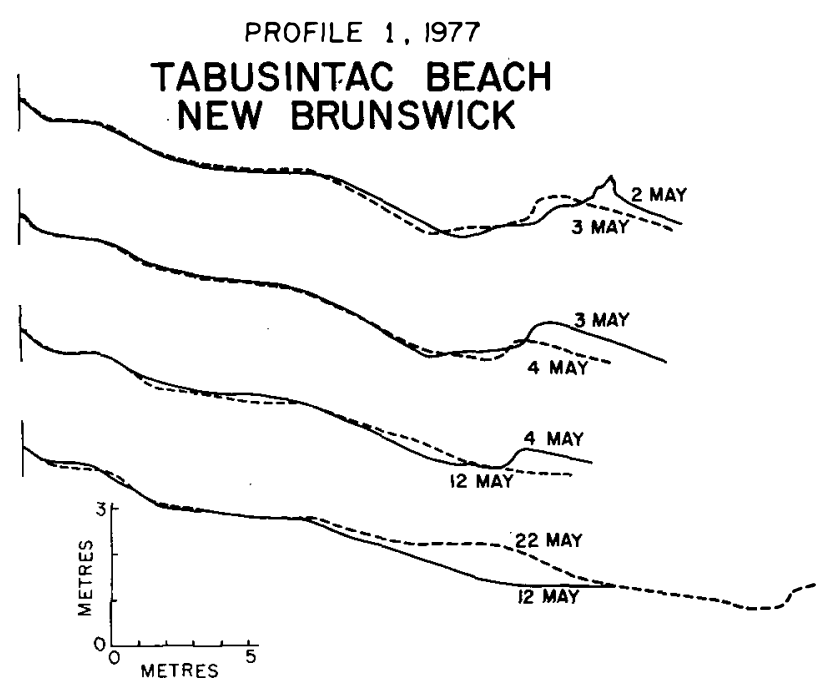

FIG. 2a Profile changes at Station 1, an ice-push ridge, 2 May-22 May.

PROFILE 2, 1977

TABUSINTAC BEACH

NEW BRUNSWICK

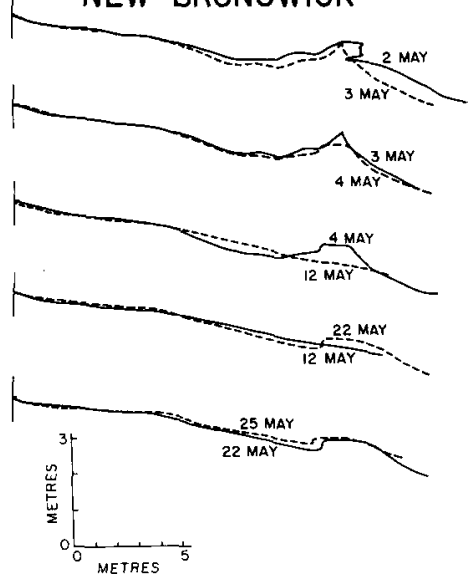

FIG. 2b Profile changes at Station 2, a kaimoo deposit, 2 May-22 May.

PROFILE 3, 1977

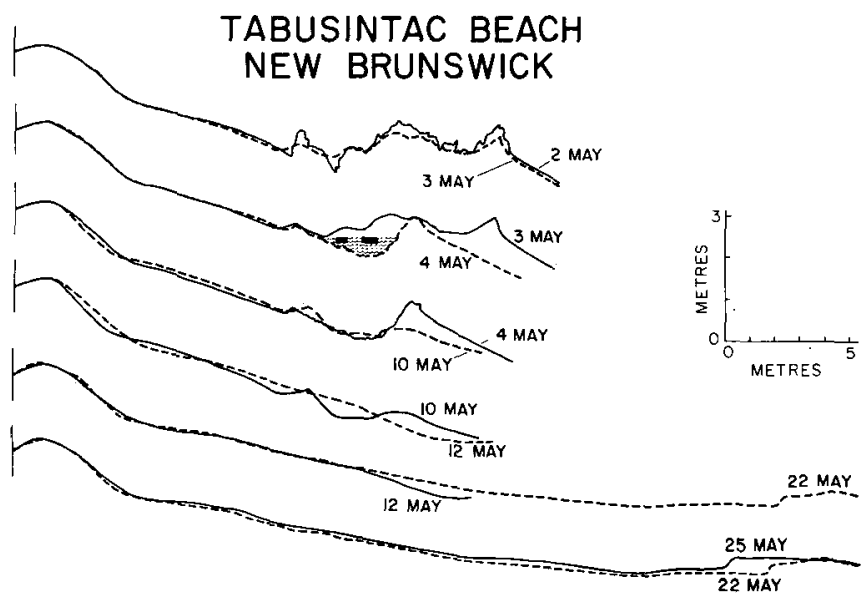

FIG. 2c Profile changes at Station 3, an ice-push ridge seaward of a kaimoo deposit, 2 May-22 May. Note development of kaimoo pond.
The ice-sediment deposit develops on the upper part of the foreshore before the formation of sea ice or ice-foot in the fall. During swash run-up, a thin layer of ice containing entrained sand forms on the upper beach. Repetition of this sequence can form beds of interlayered ice and sediment several metres thick (Short and Wiseman 1972).

Observations of the freeze-up sequence at Merigomish (Northumberland Strait, Gulf of St. Lawrence) in winter 1978 showed that the kaimoo was the first ice-sediment structure to form on the beach. It formed after the beachface had frozen, so percolation of swash into the beachface was reduced. Bagnold (1940) showed in model studies that an impermeable layer beneath a beachface (such as ice) would augment erosion due to decreased percolation. However, the shallowest water depths at the top of the swash upwash froze, locking sediment at this location. The kaimoo was morphologically similar to a ridge-and-runnel system in low energy areas (Sallenger and Rosen 1974). These features had a concave upward form, no slipface development, and a runnel-like trough filled with sediment-free ice.

Ice-push ridges are unsorted and unstratified mounds of sediment formed by waves pushing grounded ice blocks up the beachface during the ice breakup process.

The ice-foot, which is, "that part of the sea which is frozen to the shore and is, therefore, unaffected by tidal movements," (McCann and Carlisle 1972) had been destroyed at the onset of observations at Tabusintac. Generally, an ice-foot contains only small amounts of sediment (Owens 1976).

Ice-formed beach features were monitored daily along three profiles throughout the degradation process. Monitoring began on May 2, 1977, approximately two weeks after ice cleared from the nearshore region. Each profile was located at a different morphologic setting. Profile l. (Fig. 2A), at the north end of the study area, is that of an ice-push ridge seaward of a sandy backbeach. The ridge was irregularly-shaped and consisted of non-stratified, unsorted sand and cobbles in an ice matrix. The ridge elevation was about $0.8 \mathrm{~m}$ above the beachface. Profile 2 (Fig. 2B) is that of an eroding kaimoo deposit of irregularly spaced strata of sand and ice. The kaimoo surface was pock-marked by numerous sink-holes ( $<1 \mathrm{~m}$ diam), formed where the underlying ice had melted (Fig. 3). Profile 3 (Fig. 2C) is along a transect of an eroding ice-push ridge, similar in form to Profile 1, seaward of a kaimoo deposit.

\section{DEGRADATION PROCESS}

The daily profiling recorded increasing water levels with each tide. This was accompanied by increased wave attack and erosion of the seaward margin of ice features. The tide was approaching the highest spring after breakup (Fig. 4).

The beachface seaward of all three sites was frozen solidly, as determined by sounding rods. A 10 - to $20-\mathrm{cm}$ thick veneer of sand covered the frozen zone. The beachface showed a net lowering 


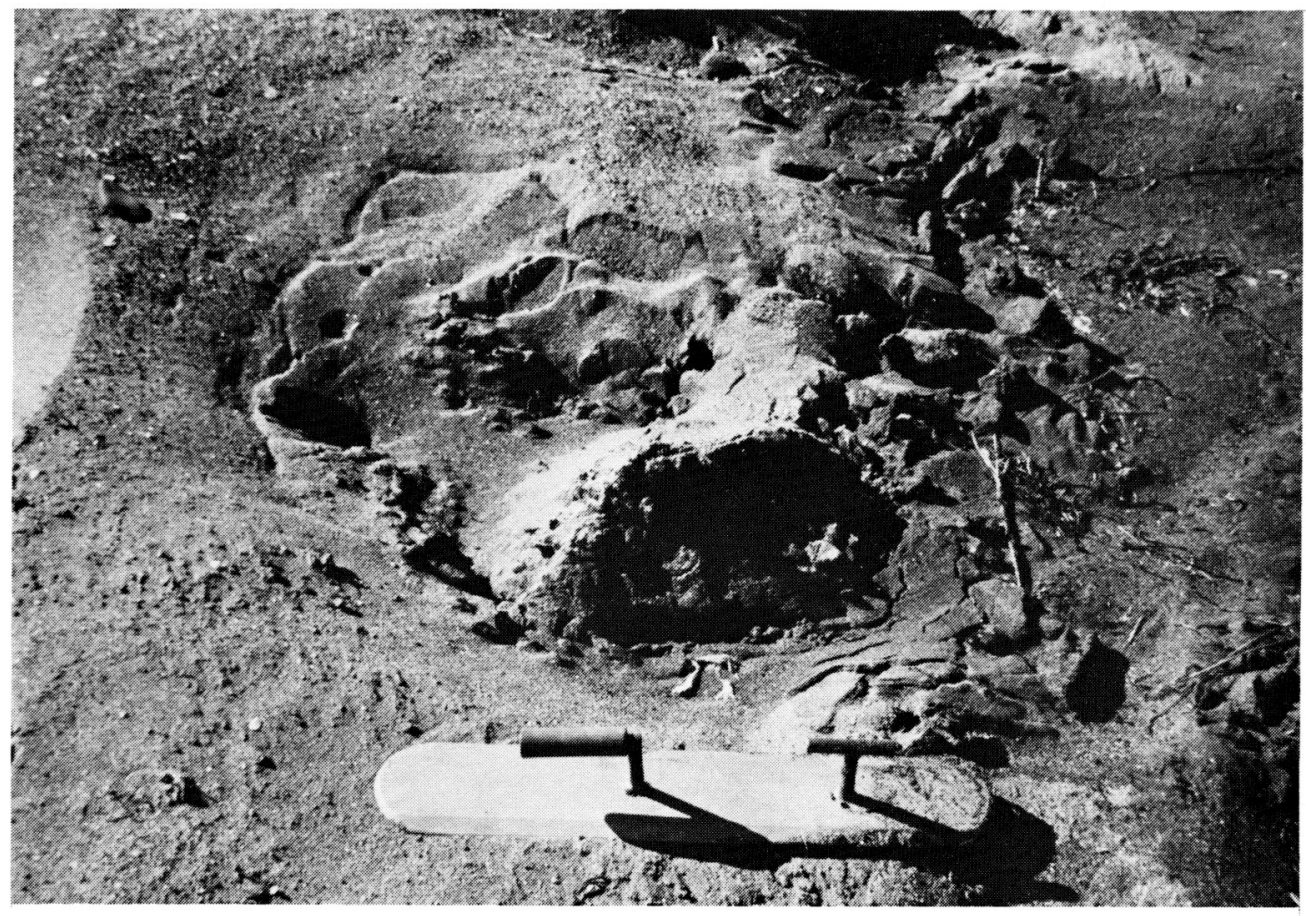

FIG. 3 Sinkhole on the surface of a kaimoo deposit. The beach-scraper is $55 \mathrm{~cm}$. long.

in elevation after each succeeding high tide. This was caused by melting of the frozen beachface by the sea water, and by increased backwash. The latter resulted from decreased perrolation of swash into the foreshore by the frozen layer. The beachface remained frozen until May 6 .

High-tide swash cut vertical scarps at the ice-push sites. The stratified kaimoo deposit of Profile 2, had been undercut at the base (Fig. 5). Examination inside this undercut revealed thick sand laminae which had been washed out by swash, leaving an ice roof. Ice blocks, up to $2.5 \mathrm{~m}$ long, slumped on succeeding tides and were carried in the swash until melted (Fig. 6). The undermined and collapsing kaimoo deposits (Profile 2) in Tabusintac contained several beds ( 1 to $30 \mathrm{~cm}$ thick) consisting of well sorted sand similar to aeolian beachface deposits found in the summer. Therefore, the aeolian processes probably had a significant sand input into the kaimoo structure in the fall.

Melt water from the kaimoo at Profile 3 was ponded by the ice-push ridges to seaward. Continued melting left a deep $(0.7 \mathrm{~m})$ pond, here termed a kaimoo pond, with large tabular blocks of ice and sand floating at the surface (Pig. 7).

The spring tides over-topped the ice features on May 3-4 resulting in numerous oyerwash channels leading into slipfaced, depositional lobes extending landward (Fig. 8). At Profile 3 the existing high (ridge) and low (kaimoo pond) topography was transformed into a ridge-and-runnel system with an initial slipface $0.8 \mathrm{~m}$ high. Ridge-and-runnel systems also formed at the other sites. The over-topping by waves caused internal melting on the ice-push ridges, planing of the surface of the features, formation of continuous slipfaces, and increased melting in the kaimoo pond (runnel) at profile 3. At this stage, the ridge-and-runnel processes of beach accretion became dominant (Owens and Frobel 1977). The size of the ridges was larger than later ridge-and-runnels formed in the nearshore, as is demonstrated in Figure $2 \mathrm{C}$. The processes of ridge migration were accompanied by diminution of ridge volume, as much of the bulk of the feature was melted ice. The ridge migrated through the kaimoo pond (runnel) at Profile 3. A small volume of sand was eventually deposited on the upper beachface to form a berm. The cobbles in the ice-push at Profiles 1 and 3 were not transported landward with the ridge, but were left as a lag deposit at the lower low water (Fig. 9). This ice-transported cobble may be significant source for the cobble transported across the beachface during summer storms.

PREDICTED HIGHER HIGH WATER LEVELS PORTAGE ISLAND, N.B.

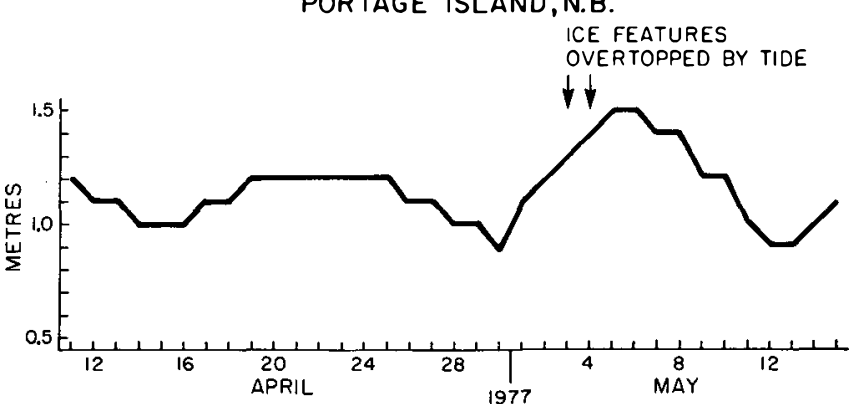

FIG. 4 Predicted higher high water levels of Portage Island, N.B., $20 \mathrm{~km}$. south of Tabusintac. 


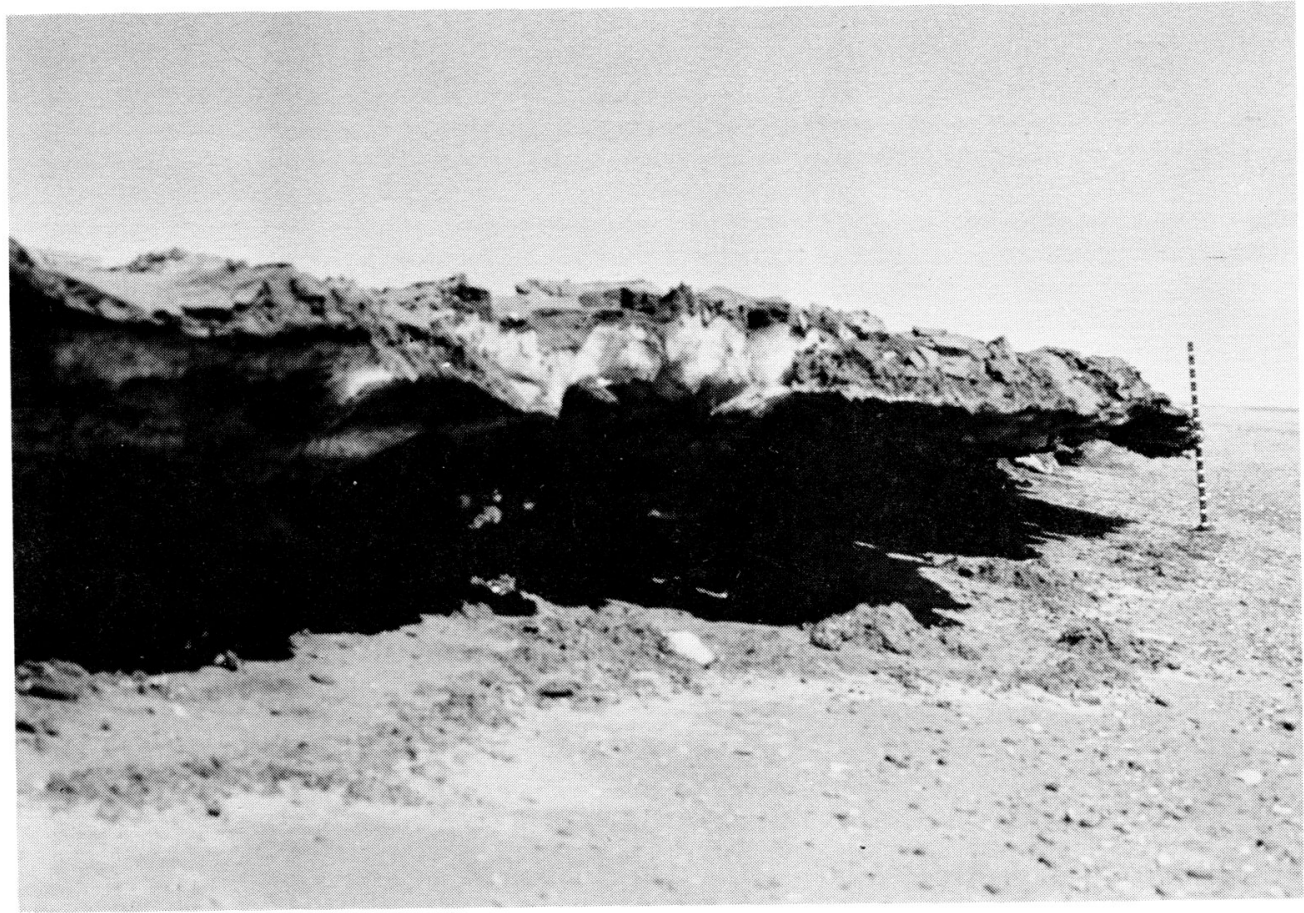

FIG. 5 Undercut kaimoo deposit at Profile 2. The scale is $1.5 \mathrm{~m}$. long.

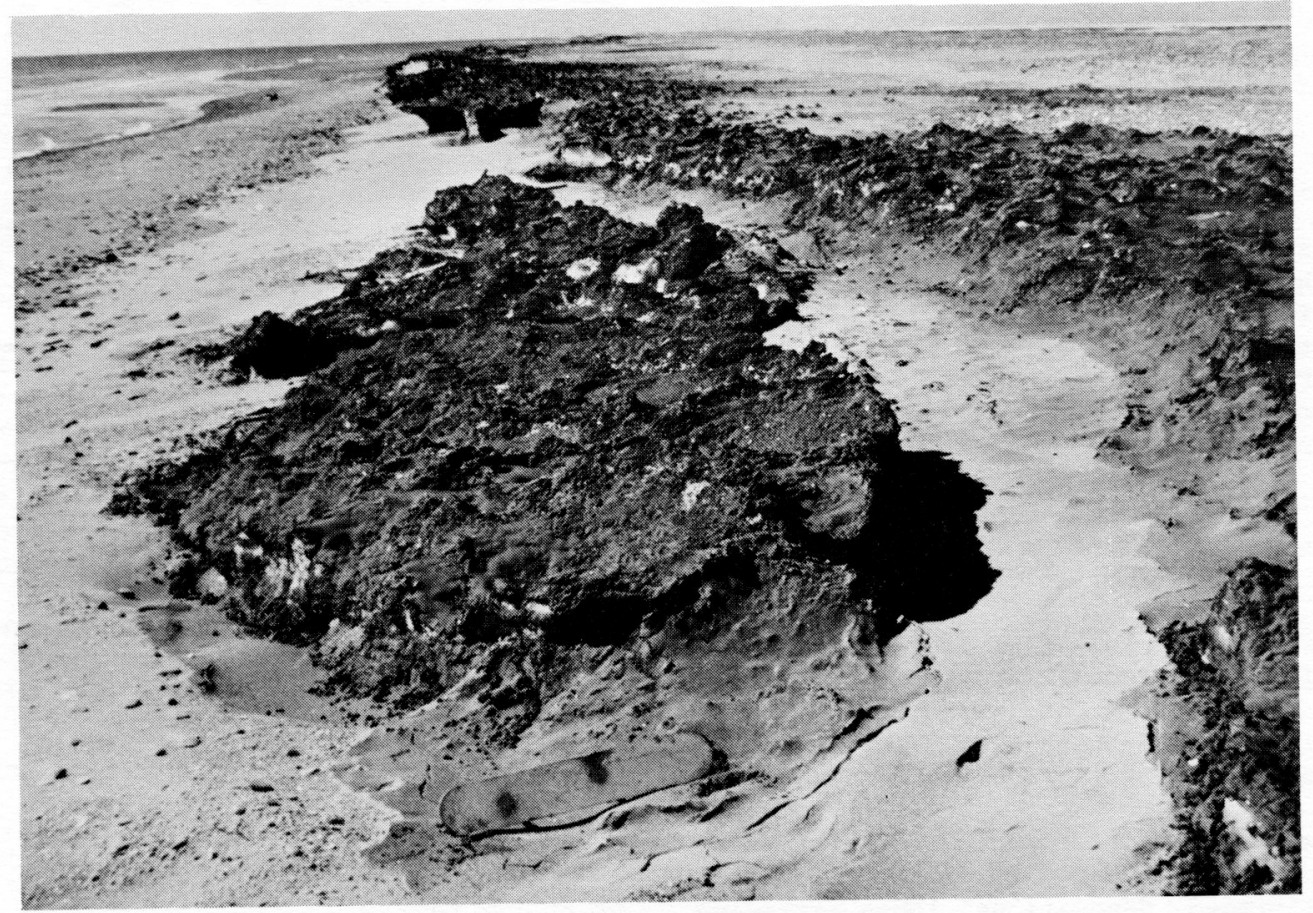

FIG. 6 Slumped ice-sediment block at Profile 2. The beach-scraper is $55 \mathrm{~cm}$. long. 


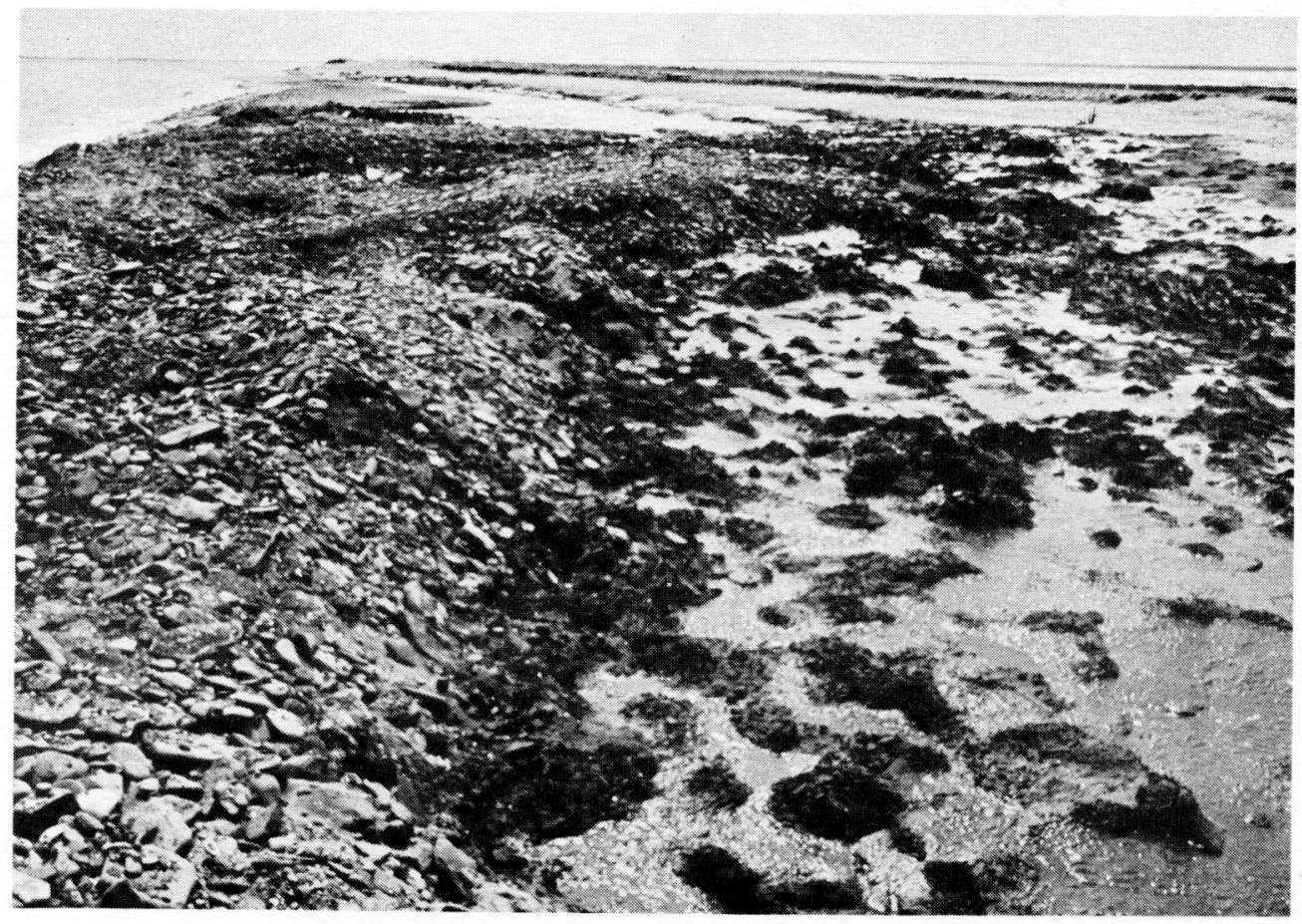

FIG. 7 Ice-push ridge (left) and kaimoo pond (right) at Profile 3 on 3 May 1977. In the background, part of the feature has been overtopped by waves and transformed into a ridge-and-runnel system.

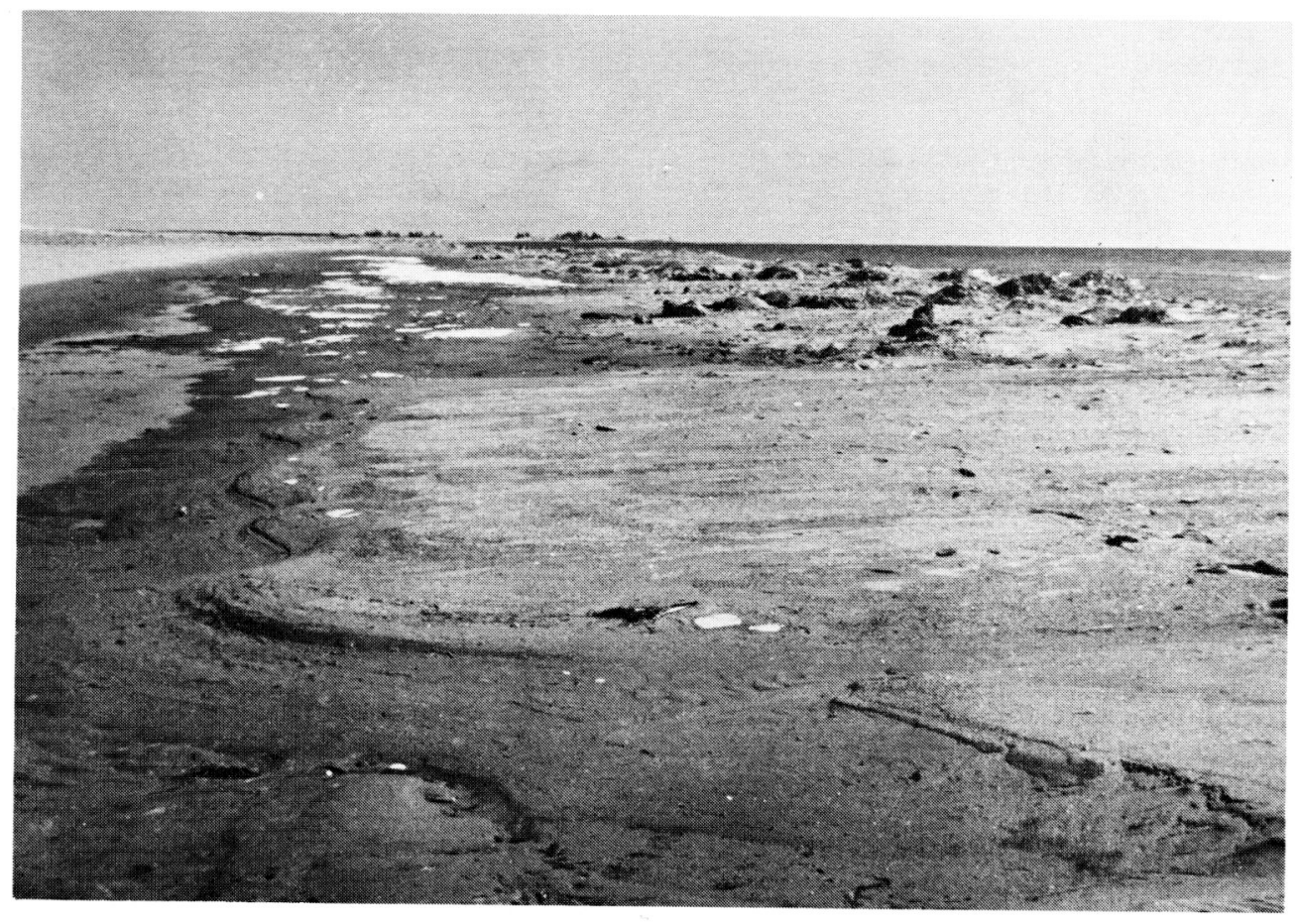

FIG. 8 Slipface developing from overtopped ice-push ridge at Profile 1, 3 May. 
68

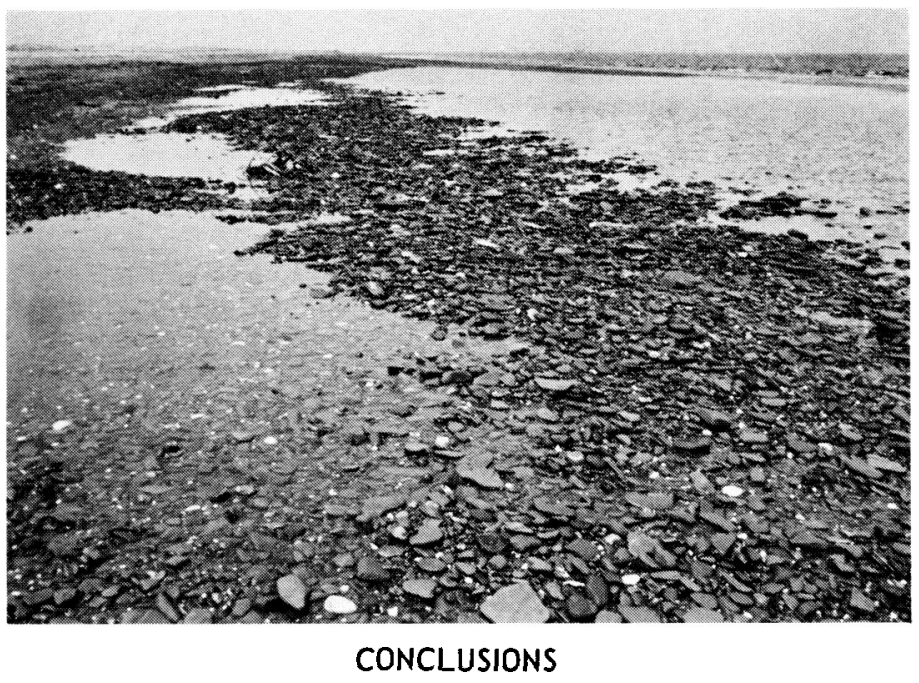

The ice-formed sediment deposits on Tabusintac Beach include ice-push ridges and kaimoos. Icepush ridges consist of cobble and sand transported from the nearshore by the landward thrusting of ice and sediment blocks by wave action. Kaimoo is a stratified ice and sand structure resulting from freezing swach and aeolian sand accumulation during freezeup. The melting of the beachface causes successive lowerings of this feature, which result in continued wave attack on the seaward face of the ice-sediment structures. The melting kaimoo deposit landward of an ice-push ridge forms a kaimoo pond.

The increased water elevations, due to spring tides, over-top these structures and transform them into ridge-and-runnel system. This augmented melting of the ice causes a diminishing volume of the ridge during landward migration. Only the sand in the initial ice-push structures is transported, leaving a cobble lag.

The ice-sediment deposits on the beachface have the following effects on the system:

1) They protect the beach from storms for a three-week period.

2) Their presence provides an alternative method of initiation of ridge-and-runnel system.

3) The sand is transported and deposited onto the upper beachface, forming the first berm of the season.

4) The cobble is left as a lag deposit at lower low water line.

Although the major impact of ice on the shore is to limit wave action and storm surge in the winter, the degradational process of the ice-sediment structures in the spring is the transition to wavedominant processes along the shoreline.

\section{ACKNOWLEDGEMENT}

This study was supported by Project 770008 of the Geological Survey of Canada. Discussions with S. Brian McCann, Bernard Pelletier and Lionel Carter proved useful in the preparation of this
FIG. 9 Gravel lag remaining at the LLW. line at Profile 3 after sand has migrated landward as a ridge-andrunnel system. This gravel may be a significant source of cobble transported across the beachface during summer storms.

paper. William Cooper provided competent assistance in the field.

\section{REFERENCES}

ATMOSPHERIC ENVIRONMENT SERVICE, 1973. Canadian Normals, vol. 1, Temperature: Environment Canada, $186 \mathrm{pp}$.

BAGNOLD, R.A., 1940. Beach Formation by waves; some model-experiments in a wave tank: Jour. Inst. Civ. Eng., vol. 15, No. 1, pp. 27-52.

MATHESON, K.M. 1967. The Meteorological Effect on Ice in the Gulf of St. Lawrence: McGill Univ., Marine Sci. Centre, Montreal, Rpt. No. 3, $110 \mathrm{pp}$.

MCCANN, S.B. and CARLISLE, R.J., 1972, The nature of the ice-foot on the beaches of Radstock Bay, southwest Devon Island, Northwest Territories, Canada: Inst. Brit. Geog., Spec. PubI. No. 4, pp. 175-185.

MOORE, G.W., 1966. Arctic beach sedimentation, pp. 587-608, in Wilimovsky, N.J. and J.N. Wolfe (eds), Environment of the Cape Thompson Region, Alaska: U.S. Atomic Energy Comm., Rept. PNE-481.

OWENS, E.H. 1976. The effects of ice on the littoral zone at Richibucto Head, Eastern New Brunswick: Rev. Geogr. Montr., vol. Xxx, Nos. 1-2, pp. 95-104.

OWENS, E.H. and FROBEL, D.H. 1977. Ridge and runnel systems in the Magdalen Islands, Quebec: Jour. Sed. Pet., vol. 47, no. 1, pp. 191-198.

REX, R.W. 1964. Arctic Beaches, Barrow, Alaska, p. 384-399, in Miller, R.L. (ed), Papers in Marine Geology; Shepard Commemorative Volume, MacMillan, New york.

SALLENGER, A. and ROSEN, P.S. 1974. Beach ridges on a low energy beach, VIMS Beach, Gloucester Point, Virginia (abs): Virginia Journal of Science, vol. 25 , no. 2 .

SHORT, A.D. and WISEMAN, W.J. 1974. Freezing effects on Arctic beaches: Bull. No. 7, Coastal Studies Institute, Louisiana State Univ., Baton Rouge, pp. 23-3I. 